\title{
The Future of the Automotive Industry: Dangerous Challenges or New Life for a Saturated Market? ${ }^{\dagger}$
}

\author{
Annamaria Simonazzi, ${ }^{*}$ Jorge Carreto Sanginés, ${ }^{* *}$ and \\ Margherita Russo****
}

\author{
Working Paper No. 141
}

November 24, 2020

\begin{abstract}
The automotive industry is undergoing a radical transformation. New social, technological, environmental and geopolitical challenges are redefining the characteristics of a saturated market, opening new scenarios while offering opportunities for the entry of new players. These challenges are bound to trigger reorganization of the global value chain between old
\end{abstract}

Previous versions of this paper have been presented in various seminars and conferences. We wish to thank the participants for useful comments and Thomas Ferguson for invaluable help. We also wish to thank the representatives of Mexican automotive companies for their time in long and fruitful visits to their factories. Financial support by the Institute for New Economic Thinking (INET) is gratefully acknowledged.

* Fondazione Roma Sapienza, Università di Roma, Italy, annamaria.simonazzi@uniroma1.it

** Facultad de Economía, Universidad Nacional Autónoma de México, Mexico, jcarreto@economia.unam.mx

*** Dipartimento di Economia Marco Biagi and CAPP Research Centre for the Analysis of Public Policies, Università di Modena e Reggio Emilia, Italy, margherita.russo@unimore.it 
and new suppliers and car makers and their suppliers, affecting the distribution of employment, the regionalization of production and the dynamic evolution of the comparative advantage of nations.

In this paper we address the issue of the reorganization of global value chains in the face of these challenges. The analysis will compare the relative position of core and peripheries in the North-American and European macro-regions, focusing on Mexico, which represents a significant case study for analysis of the impact of the digital transformation on the domestic value chain in an "integrated periphery", and of trade agreements on the location policies of big multinationals. The dependency of the Mexican automotive industry on the strategic decisions of global players is considered a factor of great vulnerability, especially in a context of rapid change in the patterns of consumption, technologies and international trade agreements.

For Mexico, as for European producers in the integrated and semi-peripheries, the main challenge in the near future will be posed by the radical transformation the industry is going through in electrical and autonomous-driving vehicles, which sees regions and players outside the traditional automotive clusters in the lead. The transformations taking place are bound to change the global structure of automotive production. The rise of new competitors from the emerging economies and would-be entrants from other sectors, competing in mastering the new digital and software technologies, threatens the established structure of the industry.

The pandemic has led to a spectacular acceleration in the process of change, while heightening uncertainty about future developments. This is why the governments of leading countries are joining in the race, wielding carrots and sticks in support of their industries and in the endeavor to encourage risk-taking and investment in research and innovation, step up e-vehicle production while providing for the necessary infrastructures, and guarantee their companies a place in the new industry.

\section{https://doi.org/10.36687/inetwp141}

Keywords: automotive industry, global production networks, integrated peripheries, Mexico, decarbonization, digital transformation

JEL Classifications: L620; F230; F630; O330; O380. 


\section{Introduction}

The automotive industry is confronting deep uncertainty in a complex and ambiguous environment (Teece, 2018). The established structure of the world industry is defined by trade wars, the rise of new competitors from emerging economies and would-be entrants from other sectors that compete to master ongoing paradigm shifts: connectivity, autonomy, sharing, and electrification (referred to by the acronym CASE, created by Daimler in 2016). These new challenges - social, environmental, technological, and geopolitical - open new scenarios: while they may entail huge costs in terms of changes in production, they can also bring new life to a largely saturated sector. Established car manufacturers must respond to the dual challenge of defending their present position and preparing for an uncertain future. The radical transformation of the industry will affect the current structure of the whole automotive value chain: it will involve different stakeholders, such as new players in battery and software production, and mobility end-users, require securing new key materials and capabilities, and call for new public policies to ensure infrastructures.

How these upstream, downstream and horizontal partnerships will play out in the future is still highly uncertain. Product commoditization and reduced value added accruing to the conventional ICE drive train may dent OEMs' [Original Equipment Manufacturers] profits. A highly volatile international trade environment - Brexit, adversarial US relations with China, the revised treaty with Canada and Mexico, a tougher American stance towards the European "allies" - largely fueled by the changing distribution of power among nations, exacerbates the uncertainty. Finally, the heavy social and economic shock due to the COVID-19 pandemic has added more uncertainty. Uncertainty's impact on the automotive sector has been large, albeit different across producers and countries. Governments have enacted policies aimed at enhancing the competitive advantage of their industries, in an effort to affect the geographical distribution of production.

Since the direction in which the present is evolving is uncertain, and alternative states are hazily defined, OEMs and their suppliers need to consider multiple hypotheses about the path of industry evolution in formulating their strategies. Deep uncertainty requires flexibility, since the price for misdiagnosing the future evolutionary or revolutionary path of the industry can be colossal. Their responses can put the fate of regional or national economies at stake. Alliances and flexible forms of collaboration (with new players and old competitors alike) offer a safer route as a way to share the risk (Teece et al. 2016): "to gain speed, to gain technological advantage, to share risk", in Daimler chief executive Ola Kallenius's words (Miller, 2020b). However, organizations' interpretation of and response to their environment 'may shape the environment' (Daft \& Weick, 1984: 287): sunk costs create path-dependence,

that's why public policy must exert a timely and decisive role in orienting towards a socially desirable outcome. 
This paper addresses the issues of the reorganization of the global value chain between old and new suppliers and their implications for the dynamic evolution of the comparative advantage of nations, the regionalization of production and for employment. The analysis will compare the relative position of core and peripheries in the North-American and European macro-regions.

The research relies on specialized literature, on the analysis of trade data, and on the Mexican and the US data on the automotive industry presented in two companion papers (Russo et al., 2020; Carreto, 2020). A complementary source of information, direct interviews with companies, has been only partially explored. As a consequence of COVID-19, the research team had to stop the field work, and only the interviews already done in Mexico in 2019 (Carreto et al., 2019) and in 2020 will be used in the present report. In a further stage of the research, we plan to organize online interviews with companies in Mexico, Italy, and possibly Germany. In addition, secondary sources of information and specialized newsletters (such as electrive.com on electric vehicles) will be explored with text mining techniques to identify the ongoing trends in OEMs and their Tier-1 suppliers.

The paper has the following structure. Section 2 provides a description of the automotive sector before the COVID-19. It shows how the network of international trade changed over time by using a multilayer network analysis to single out clusters of countries and their specific trade networks. Section 3 focuses on the integrated peripheries of the North-American and European macro-regions and their relations with the core and semi-peripheries. The critical issue of dependence in the development process is discussed in the following section 4 with reference to the case study of the Mexican automotive industry. Finally, Section 5 considers the OEMs' strategies to cope with the epochal transformation of the auto industry brought about by technological and product innovations. The last section summarizes the further steps in the ongoing research project.

\section{The hierarchical regionalization of production and trade}

The automotive industry is highly concentrated: in 2018 the top 20 car manufacturers employed approximately 75 per cent of all employees working at car manufacturers worldwide and contributed with about 88 per cent of the global vehicle production volume (Hoeft 2020). It is also one of the most globalized industries: historically highly clustered in core areas, since the late 20th century it embraced global sourcing, with peripheral areas taking on more prominence. The reorganization of the automotive supplier industry was made possible by new transportation technologies and logistical systems, and by technological and organizational changes that significantly reduced the number of suppliers and organized the remaining ones into tiers. The requirements of just-in-time production, along with local content and the request by OEMs to their main suppliers to be followed in their new locations (follow sourcing), led to the increased clustering of especially Tier-1 suppliers around assembly plants (Sturgeon et al, 2008; Pavlínek 2018). Global sourcing was triggered by the profit-seeking 
strategies of firms that exploit countries' differences in levels of developments and factor costs, shifting production between countries (Harvey 2014). The need to "produce where you sell"1 has added to the production diaspora. The geographic structure of the automotive industry is now based on the presence of large assemblers and leading (global) suppliers in all major markets, organized in functionally integrated macro-regional production networks. The competitive process results in the dynamic nature of nations' position within automotive production networks, with production moving between core, semi-periphery and integrated periphery.

In a companion paper, Russo et al. (2020) analyze these changes in international trade in the automotive global value chains using network analysis, which allows them to study the centrality of given regions and countries. The paper runs the analysis at a very disaggregated level, to account for the contribution of the various automotive components and parts in structuring the relative position of countries. ${ }^{2}$ There are three main issues. The first one concerns the geography of trade relations: which are the countries at the core of the international trade of automotive components? The second one points out which products/groups of products characterize the relative positions of countries. The third issue concerns the changes in the relative positions of countries and specializations over time.

To answer these questions, the authors map the geography of the trade relations that emerge from community detection, implemented by using Infomap multilayer analysis (we refer to the paper for the technical explanation). The analysis considers exports of:

- 30 commodities, grouped in four main categories: Electrical and Electric Parts, Rubber and Metal Parts, Engines and Parts, Miscellaneous Parts

- 42 reporting countries (representing approximately $98 \%$ of total world exports of automotive components and parts)

over the period 1993-2017: three-year averages around 1993, 2008, 2013, 2017. The dataset is the UN Comtrade International Trade Statistics Database.

Before summarizing the main results a note of caution is required: the network is based on foreign trade, thus it cannot trace the changes in production directed to serve the domestic market. This implies that it cannot account for the changes in the value chain that occur through direct production in foreign markets rather than through exports.

An overview of the changes in the centrality of countries (weighted both by exports and imports passing through the node) between 1993 and 2017 is provided in Figure 1. It shows the expansion of the network of trade and countries' changing importance: the appearance of what we will call 'integrated peripheries' (Mexico and CEE countries), the downsizing of some core countries (UK, Canada), and the entry of China.

${ }^{1}$ Ola Kallenius's (Daimler's chief executive) interview with the Financial Times (Miller 2020a).

${ }^{2}$ See Gorgoni et al (2018) for a similar analysis, discussed in Russo et al (2020). 


\section{Figure 1 - Network of bilateral trade of automotive components and parts, 1993 and 2017}

Nodes [countries]: size proportional to Weighted.Vertex.Degree.all; Edges [export trade flows]: thickness proportional to weight, compared to the maximum share in 1993 and 2017; Color of edges: 5 classes defined on the basis of the distribution of shares in 1993 and 20

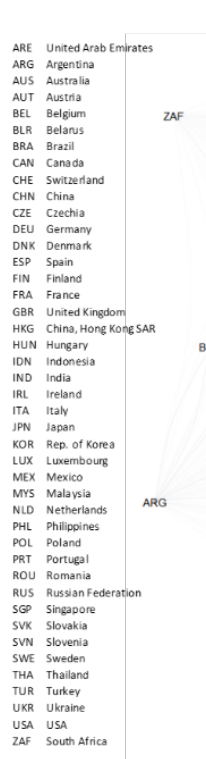

1993_42 countries

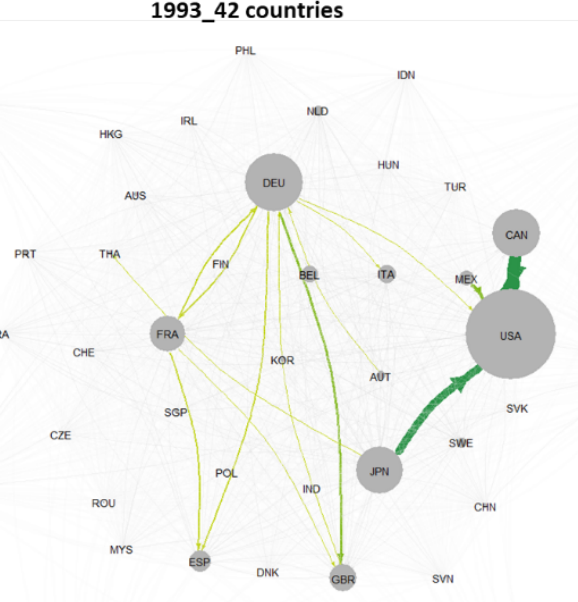

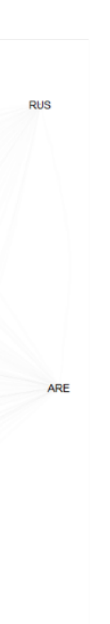

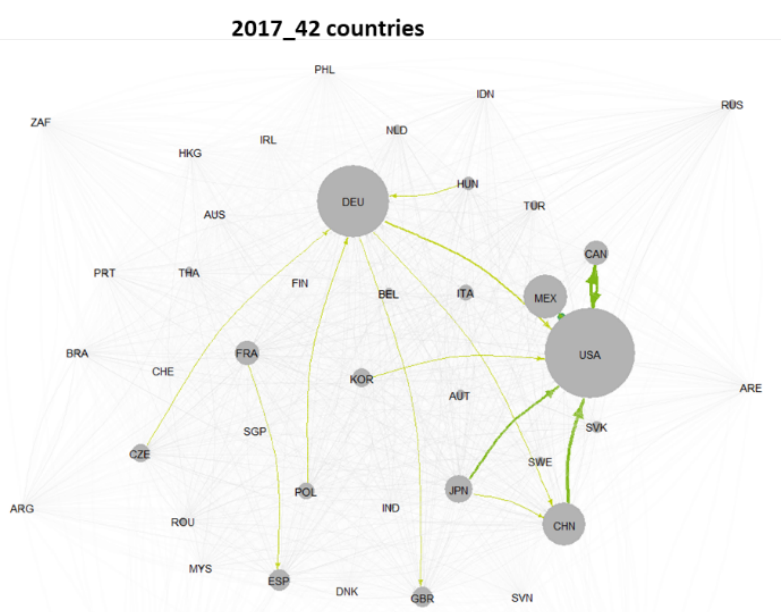

Source: Russo et al. 2020.

A preliminary analysis of the weight of the 4 groups of parts and components reveals a relative stability over the entire period, with a few notable adjustments within the groups ${ }^{3}$ (Table A1 in Appendix). This seems to suggest a relative stability in the production technology in the period under consideration: the great transformations of the industry currently underway are not yet clearly perceptible in the composition of parts and components.

The main descriptive statistics of the network of export flows (Table 1) show that over the 26 years considered, the overall average number of countries (nodes) does not change significantly, while the size of the networks increases, indicating a greater number of interconnections among countries over a larger number of commodities, and, accordingly, an increase in the mean degree (indicating the average number of components traded).

Table 1 - Main network features, per year

\begin{tabular}{ccccc}
\hline $\begin{array}{c}\text { Average data values per } \\
\text { layer }\end{array}$ & $\mathbf{1 9 9 3}$ & $\mathbf{2 0 0 3}$ & $\mathbf{2 0 1 3}$ & $\mathbf{2 0 1 7}$ \\
\hline n.nodes & 41.7 & 42.0 & 40.9 & 40.8 \\
Size & 758.3 & 1088.2 & 1218.3 & 1200.9 \\
Mean.degree & 18.1 & 25.9 & 29.0 & 28.6 \\
\hline
\end{tabular}

Source: Russo et al. 2020.

${ }^{3}$ We can mention the doubling of 'electrical accumulators (storage battery)' and 'electrical lighting or signaling equipment', and the almost halving of 'reciprocating internal combustion piston engines for propelling vehicles' (Table A1). 
The data on export value shares by country (Figure 2) confirm the expansion of the network of trade: in 1993 five countries - Japan, USA, Germany, France and Canada - accounted for $67.3 \%$ of total exports of automotive parts and components, and for only 44.8 per cent in 2017. Only Germany manages to maintain its share (right panel). China, Mexico, Korea, and the Central and Eastern European (CEE) countries (marked in turquoise blue) increase their share as a whole from $7 \%$ in 1993 to $33.3 \%$ in 2017.

Figure 2- Export by country, in 1993, 2013, 2003 and 2017, share of trade values, by year

trade share by year

Countries are ranked according to their 1993 total export

share towards the 42 countries [ values at current price]

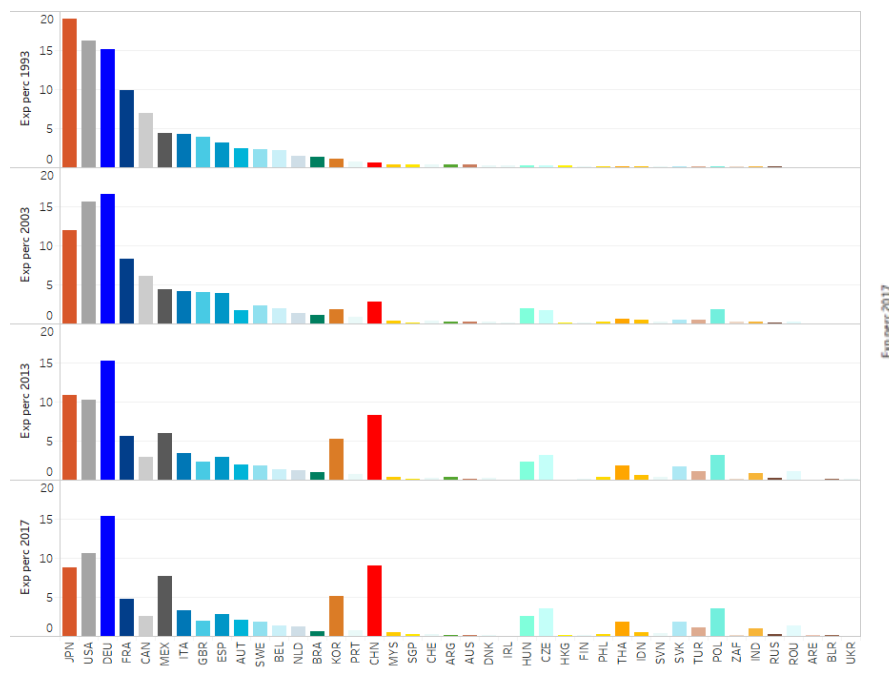

trade share in 1993 vs 2017

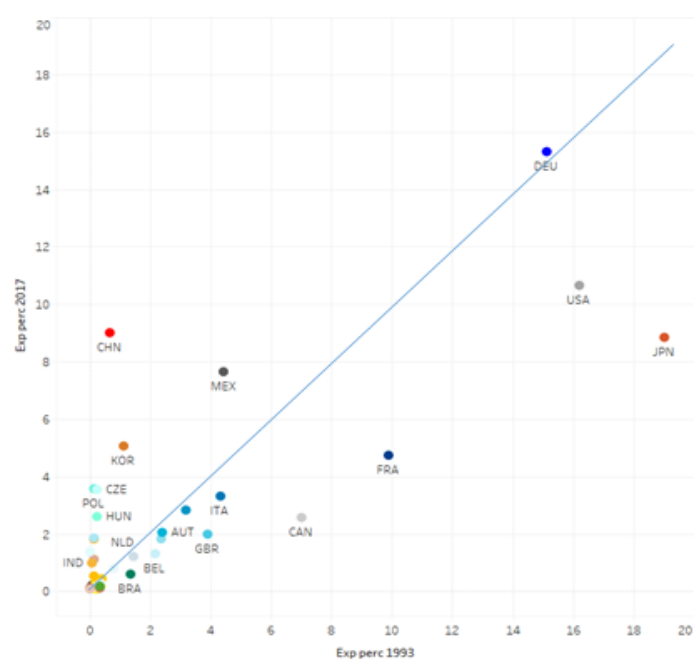

Source: Russo et al 2020

The expansion of trade is usually interpreted in the light of the increasing relevance of global value chains. However, the expansion of trade went hand in hand with the formation of networks that may or may not correspond to macro-regions. Community detection can highlight those groups of countries whose trade in the 30 components create relatively more connected trade areas (see Russo et al., 2020 for details on the methodology for the detection of clusters).

Figure 3 summarizes the results on community detection: i) horizontal bars show the share of each cluster, ranked in decreasing order of total Infomap flow; ${ }^{4}$ ii) vertical histograms display the share of each country, with the color assigned to identify the community it belongs to in that year; and iii) the interconnections between communities are represented in the graphs realized with the visualization of Infomap Network Navigator. In the graphs: clusters are drawn as circles with area proportional to the intra-cluster flows; the border thickness

\footnotetext{
${ }^{4}$ The clusters are identified by color: for instance, dark blue identifies the cluster centered around Germany; grey the cluster centered around the US; orange for East Asia (Japan, China, Korea, etc.).
} 
is proportional to exiting flows, links between nodes are aggregated on cluster level and their thickness is proportional to the flow between clusters. ${ }^{5}$

The weight of the various clusters varies through time: we observe a general descending trend for the North-American cluster, and a continuous increase of the Asian. The 'European' cluster loses ground between 1993 and 2013 (from 52\% to 40\%) to regain ground in 2017 (46\%). The performance of this cluster is certainly due to the rise of the CEE countries (as can be seen from the histograms), but also to the performance of Germany: the only country, unlike the United States and Japan, to have managed to maintain its export share, in the face of the growth of China, S. Korea, and Mexico.

${ }^{5}$ The relative size of edges is kept large enough to make visible all the relevant connections among clusters, there is no proportion between edges' size and circles' size. 
Figure 3 - Infomap flow and network of clusters, by year

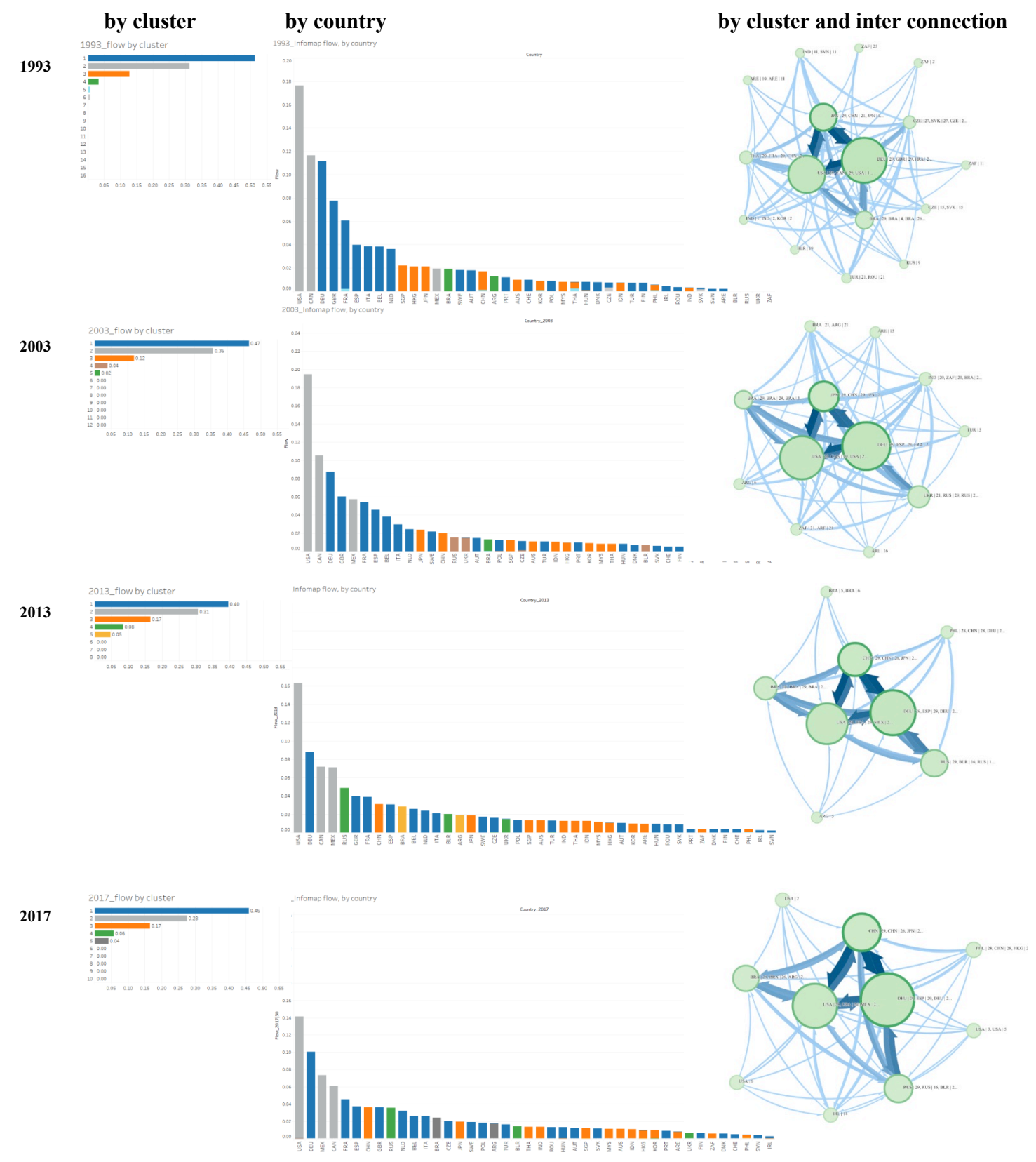

Source: Russo et al. (2020).

In the end, the spatial distribution of clusters is largely associated with the geographical position of countries, so that we can speak of the organization of trade in macro-regions, somehow redefining the 'global' in global value chains. The size of the circles suggests that much trade occurs within the macro-regions: GVCs had already been shortened by OEMs localization and follow on sourcing. Moreover, community detection can single out specific subclusters - such as Thailand and the Czech Republik and their communities in 1993 - that later merged into other clusters (respectively, in the ASEAN and the European one). 


\section{Integrated peripheries: Mexico and the Central European Economies (CEE) com- pared}

Production facilities in Europe and North America have been increasingly located in peripheral regions - Central Mexico in North America and former Communist countries in Central Europe - a trend that accelerated in the 21 st century (Brincks et al 2018), giving rise to what came to be known as the 'integrated periphery'. Cheap labor, geographic proximity to large markets, membership in regional trade agreements, and investment incentives (Pavlínek 2018, Mordue and Sweeney 2020; and the references cited in these papers) explain the growth of an automotive industry in these countries and the simultaneous restructuring in both traditional core regions and old integrated peripheries in Western Europe and North America ${ }^{6}$.

There are similarities between the development of the automotive industries in Mexico and in the CEE (Czech Republic, Hungary, Poland, and Slovakia): they are both tightly linked to (or dependent upon) a powerful player and have recorded an impressive growth in production, brought about by FDI lured by low wages and policy incentives. The German-EEC network grew thanks to the access of the Eastern countries to the European common market. Likewise, the growth of the Mexican automotive industry has been shaped by tariff agreements with the US and Canada (Maquila first, then NAFTA since 1994, and now the USMCA).

Between 1990 and 2015 in Eastern Europe an influx of automotive FDI in excess of E35 billion led to growth in output from 797 thousand to 4.1 million cars (OICA 2018 quoted in Pavlínek 2020). The output of the supplier industry grew even faster with at least 1212 supplier factories built by foreign investors between 1997 and 2016 (Pavlínek 2020). Similarly, a flow of over 23.2 billion dollars in new investments (announced or put to use) since 2013 made Mexico the seventh largest vehicle manufacturer and the fourth largest exporter in the world (Negocios ProMéxico, 2015). Assembly firms' requests for their most important module and Tier-1 suppliers to be located close to assembly plants has led to the spatial restructuring of the supplier base and its concentration close to the assembly plants (Klier and Rubinstein 2020), with a sustained growth in employment in the production of parts and components (table 2). Compared to the US, Germany has offshored a higher share of production of components (the CEE + SEE accounts for 63.1 per cent of the total jobs in the production of components in the integrated macro-area against Mexico's 53.8 per cent). Conversely, Germany has retained at home a higher share of employment in assembly.

${ }^{6}$ A similar, though more recent, trend is underway in East Asia, where Vietnam and Thailand are acquiring increasing importance in world production. 
Table 2 - Employment in the automotive industry (vehicles and parts) 2016. (thousands)

\begin{tabular}{|c|c|c|c|c|c|c|}
\hline & Assembly & Parts & Total & $\begin{array}{l}\text { Assembly/ } \\
\text { total }\end{array}$ & $\begin{array}{l}\text { Share } \\
\text { core/periphery } \\
\text { assembly }\end{array}$ & $\begin{array}{l}\text { Share } \\
\text { core/periph- } \\
\text { ery parts }\end{array}$ \\
\hline US & 180.9 & 579.9 & 760.8 & 23.8 & 74.7 & 46.2 \\
\hline Mexico & 61.1 & 674.4 & 735.5 & 8.3 & 25.3 & 53.8 \\
\hline Total & 242.0 & 1254.3 & & & & \\
\hline Germany & 480.0 & 340.4 & 820.0 & 58.5 & 78.8 & 36.9 \\
\hline CEE+SEE & 129.0 & 583.0 & 712.0 & 18.1 & 21.2 & 63.1 \\
\hline Germany +CEE & 609.0 & 923.4 & & & & \\
\hline Rest of Europe & 1001.0 & 748.0 & 748.0 & 57.2 & & \\
\hline Total Europe & 1610.0 & 1671.4 & 3281.4 & 41.7 & & \\
\hline
\end{tabular}

Source: US and Mexico Klier and Rubenstein (2017, fn.2 p. 23)

Germany (2017): Krzywdzinski (2019, p. 224), from VDA (Verband der Automobilindustrie) 2016

https://www.vda.de/en/services/facts-and-figures/facts-and-figures-overview.html

Notes: CEE + SEE (4 Visegrad countries + Romania)

Governments' strategy in the integrated periphery has been based, essentially, in checking wages and attracting FDI through fiscal concessions. According to Covarrubias (2020), Mexican wages did not grow in the NAFTA era, despite employment growth and skills shortages. He notes that the same trend was recorded in the US and Canadian auto industries: over the same period wages fell from 36 to 27 dollars per hour in the US and from 34 to 26 dollars in Canada $^{7}$. In 2018, Mexican wages in manufacturing were less than one fourth the US value (Carreto 2020), an issue that is taken up in the new North American free trade treaty (USMCA) (see following section).

Figure 3 -Mexican wages and salaries in manufacturing: comparison with various countries

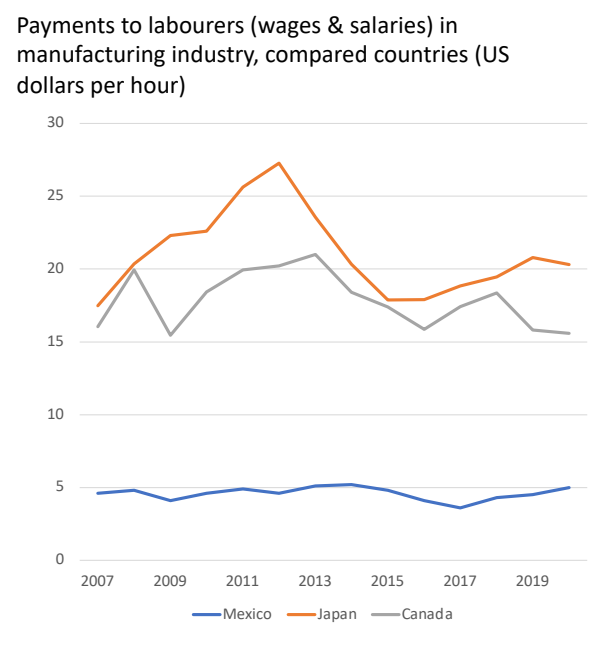

Wages in manufacturing industry, compared countries (US dollars per hour)

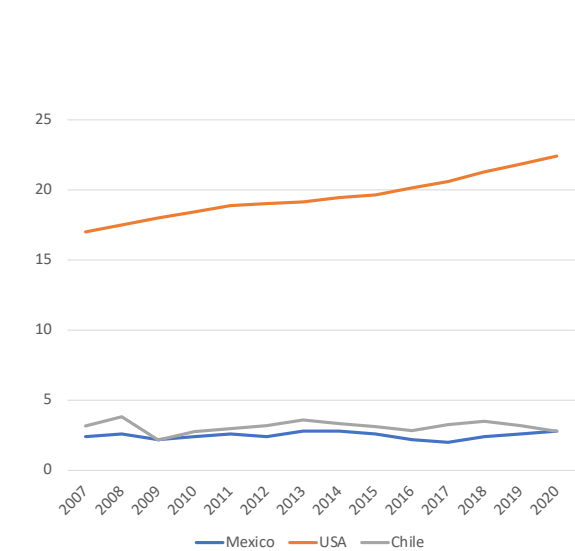

Source: Carreto (2020)

${ }^{7}$ A study of the largest exporting economies conducted by The Boston Consulting Group (2014) indicates that since the beginning of the new century the United States and Mexico recorded the smallest growth (strictly negative) in wages with sustained production. Mexico is the most cost-competitive (i.e., low cost) manufacturing country amongst the leading ten export economies, while the United States occupies the fourth place, after China and South Korea (quoted in Covarrubias and Perez 2020, 472). 
As for the CEE periphery, in 2016, the median value of wages for production workers in Poland, Slovakia, Czech Republic and Hungary were around 27 per cent of the German peer group (€835 compared to $€ 3,122) .{ }^{8}$ Strong wage increases in CEE characterized the period from the mid-1990s to the mid-2000s. Wages in the CEE automotive industry rose during this period from about 8-10 per cent of the German level to about 20-25 percent (see Galgóczi 2017 for national average wages). Between 2008 and 2016, this catching-up movement stalled, with wage increases in the Czech Republic, Hungary and Poland remaining below the increases in Germany when expressed in euros. Renewed wage dynamism in CEE after 2016 has not, as yet, restored the pre-crisis momentum of wage catch-up: weak unions, decentralized collective bargaining systems, and locational competition inside and outside the CEE combined to restrain wage increases (Krzywdzinski, 2019).

Competition over labor costs and governments' incentives are an important driver of the dynamic nature of a nation's competitive position within automotive production networks. The threat represented by lower-cost locations is used to kill wage increases across the entire production network. Delocalization, interplant competition and threats of relocation of production put pressure on higher-wage core and semi-periphery countries. Similarly, as cost advantages get eroded, integrated peripheries too fall victim of the shift to new peripheries. With wages much lower than the CEE, Romania, Ukraine, Turkey, and North Africa are becoming important recipients of FDI, especially in labor-intensive low-skill automotive assembly, such as the assembly of cable harnesses (Pavlínek et al, 2017). In turn, investment in low-cost regions offers only a temporary competitive advantage to the off-shoring firm, as other firms invest in similar locations, setting off the cumulative race to delocalize that spreads its effects on wage devaluation throughout the value chain.

\section{Core and semi-periphery}

In developed countries, the process of delocalization of production has caused concern over the future of established high-wage locations. Their firms attempted - with diverse success - to counter the saturation of their markets by upgrading to premium vehicles and exporting to the rapidly expanding markets of the emerging economies, while delocalizing the production of lower-value cars. If, as argued by Mordue and Sweeney (2020), for the integrated periphery the question is how to upgrade to the semi-periphery, for the members of the core the question is how to retain their core-like status and avoid relegation to the semiperiphery.

Relocation to the East has put strong pressures on German and other core and semi-periphery countries' production plants. Pavlínek (2020, 517-18) reports that between 1991 and 2017 ,

\footnotetext{
${ }^{8}$ There is a large variance within CEE. The lowest wages for production workers are usually paid by electronics and interior parts companies. At around $€ 300-400$ per month, they are just above the minimum wage level in the region and barely enough to survive. But wages can go up to 1400 euros in best-paying companies (Krzywdzinski 2019, 223).
} 
the traditional European automotive industry core countries - with the exception of Germany, and to a lesser extent an increasingly semi-peripheral Britain - suffered steep declines in domestic car production: France (-49\%), Italy (-56\%), Sweden (-24\%), with the deepest declines during the 2008-2009 economic crisis (figure 4). Between 2000 and 2017 also several older integrated peripheries suffered declines - Belgium (-63\%), Portugal (-29\%), the Netherlands (-28\%) (OICA, 2018). The declines in France and Italy compared to the growth in Germany can be partially attributed to the more extensive offshoring of car assembly by French and Italian automakers which, in turn, is related to a greater share of small cars in their product portfolio, as well as to Germany's large exports of mostly premium cars to China (Celi et al, 2018). ${ }^{9}$ At the same time, German automakers offshored a greater proportion of the production of components, especially to Eastern Europe, in order to benefit from its lower labor costs, attaining a more efficient intra-corporate division of labor.

Figure 4 - Car production trends in Europe, including Turkey and Morocco, 1991-2017

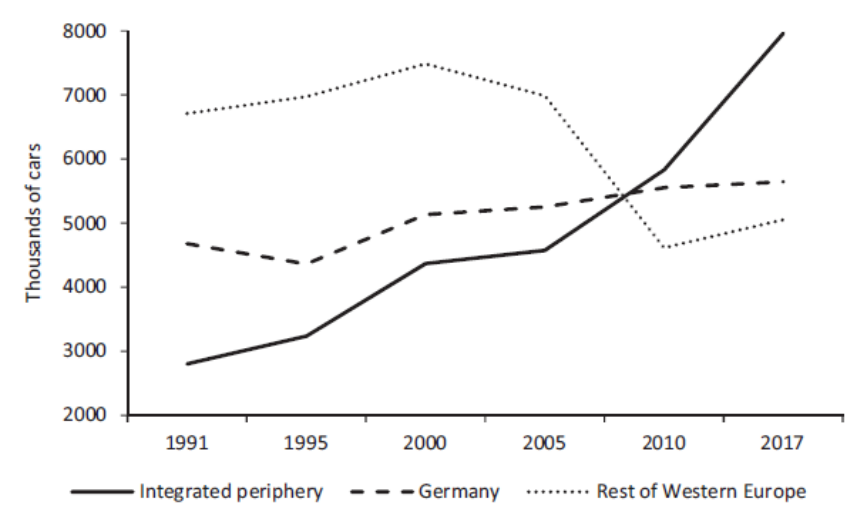

Source: Pavlínek (2020, p. 518) on data of the European Restructuring Monitor (ERM) (ERM, 2017).

German locations were under great competitive pressure. Shifts in jobs to low-wage countries have resulted in concession bargaining at many automotive supplier locations to prevent relocations or to gain new products for the plant (Krzywdzinski 2019). Only locations with lead roles in introducing new products and technologies were able partially to escape cost competition and increase employment. Conversely, the large number of pure manufacturing plants without noteworthy innovation functions, that still exist in Germany in direct competition with low-wage locations, bear the pressure to lower wages, increase working hours,

${ }^{9}$ Pavlinek (2020, p. 514) refers to the increased production of luxury cars and a simultaneous decrease in the assembly of small cars in Germany, partially relocated to integrated peripheries after 1990, as an example of this strategy. By 2010, the share of small and compact cars produced abroad reached $67 \%$ for German and $72 \%$ for French automakers, while the assembly of $93 \%$ of the upper-medium and $96 \%$ of luxury cars took place in Germany (Danyluk, 2018). A different share of luxury cars may account for the different distribution of employment between the OEMs of the same country. Miller (2020b) reports that "Unlike Volkswagen, which has just 40 per cent of its workforce in Germany, more than half of Daimler's 300,000 or so staff are based in its home country". 
intensify work processes and make them more flexible. ${ }^{10}$ Thus, behind the aggregate employment figures, an intense process of churning is taking place: Pavlínek (2020, p. 527) found that both large German and French automotive firms were shedding jobs in their home economies while creating the majority of new jobs abroad, mostly in the CEE. At the same time, domestic firms in the fiercely competitive supplier industry, which is increasingly dominated by large TNCs and follow sourcing, are getting weaker. In order to survive, large West European suppliers have been forced to internationalize production by setting up factories in the integrated periphery to supply foreign assembly plants and to export directly from there.

Often, the strategy at the corporate level may involve putting its plants located in different locations in competition with each other. For instance, decisions on awarding new models are being made more and more directly in the form of auctions between the company's various plants. When the interests of a country and the strategies of its flagship companies come into conflict, wage concessions, public incentives and veiled or open threats enter the negotiations.

Survival gets tougher for countries in the semi-periphery. The term defines wealthier automotive-producing countries that, unlike "core" nations, lack (or have lost) a domestically headquartered automaker. Unlike integrated peripheries, semi-peripheries cannot rely on labor cost advantages to retain their plants and employment, nor can they count, like core countries, on the benefits brought to the nation by its flagship companies. For economically advanced locations, a primary response to wage competition and deindustrialization lies in focusing on higher value-added activities and research and development. However, empirical studies on the automotive industry found that R\&D tends to concentrate in locations proximate to corporate headquarters (Mordue and Sweeney 2017). Thus, for countries or regions lacking a global lead firm, generating R\&D can be problematic. Moreover, because of domestic political pressures, lead firms are more likely to close assembly factories in foreign locations than in their home countries, which makes the foreign-owned factories in semiperipheries more vulnerable to plant closure than domestic assembly plants in core regions (Pavlínek 2020,514). Their weakness may also be passed on to their value chain of producers of parts and components, especially if they lose their close ties with major assemblers. Italy is, in some way, moving towards the semi-periphery. Between 1998 and 2018 it recorded a drop in the production of vehicles of 1.3 million, obliging suppliers of parts and components to increasingly rely on external production networks. As a consequence, the structure of employment changed drastically, from 40 per cent in parts and components and 52 per cent in final assembly in 1998 to 53 and 41 per cent respectively in 2018 (Gaddi 2020, p. 136).

It is an open question whether the introduction of frontier technologies, such as those supporting autonomous and electric vehicles (AV and EV), represents an opportunity for an industry revival or rather a threat of decline. In fact, the new players in digital innovation are

${ }^{10}$ See Krzywdzinski (2014) on the effects of de-localization on German labor industrial relations. 
concentrated in places other than those of the traditional automotive industry. The strategy followed by OEMs to recover lost ground in these innovations is to enter into research partnerships with the innovators. However, recovery may be more difficult for producers in integrated and semi-peripheries, which lack the research centers that are usually located at OEM headquarters. The case study of Canada seems to suggest that "even though AV-related R\&D has emerged from non-traditional automotive locations, the preponderance of AV-related R\&D is converging in core automotive locations proximate to automakers' global headquarters" (that is, in the Michigan region) (Mordue and Karmally 2020).

\section{Developmental vs dependent linkages}

The recent history of the automotive industry presents examples of successful up-grading from periphery to core status (South Korea, China) as well as examples of failed catching-up (Brazil, Mexico), and even of potential fall from core to semi-periphery (Canada, the UK, will Italy be next?). The analysis of the factors determining the prevalence - or the creation - of developmental over dependency linkages transcends the scope of this paper. Economists agree that developmental linkages are based on long-term collaboration between foreign subsidiaries and domestic firms that favor technology and knowledge transfer from foreign subsidiaries, encouraging the upgrading of domestic firms. Conversely, shorter-term, cost cutting and price-based relationships between foreign subsidiaries and domestic firms create dependent linkages, perpetuating the dependency of firms and regions on external actors (Coe and Yeung 2015; Pavlínek 2018). This distinction leaves the question of what makes for long-term collaborative links, or vice-versa, unanswered, calling into question the interaction between corporate strategies and states policies, as shaped by their relative power relations (as demonstrated by the Chinese case, Teece 2019).

In 1950, Singer (1950, p. 474) warned that the entry of foreign capital into developing economies would create a dualism of the productive structure, that is, the co-existence of firms at very different levels of technology. Likewise, the economists of CEPAL emphasized the need for indigenous "technological densities" to avoid technological dependence, advocated a coordinated policy of import substitution and export promotion; and stressed the role of the domestic market. Import substitution industrialization (ISI) and export-oriented industrialization - they argued - are not two alternative models of development, as demonstrated by the East-Asian development strategy, incorrectly depicted as export oriented ${ }^{11}$.

Both Mexico and the CEE behave as export platforms ${ }^{12}$, with an extremely narrow domestic market (saturated by imported secondhand cars). The issue of their capacity to transition to

\footnotetext{
${ }^{11}$ Zhu $(2007,1,14)$ writes that the development strategies of Taiwan and China have always been a combination of import substitution industrialization (ISI) and export-oriented strategies. "Behind this strategy there is a set of institutions which has played a key role in supporting ISI, in particular, the government, the bank sector, public enterprises, and their relationship".

1282 per cent of Mexico's automotive production is exported, 84.5\% of which goes to the US (Covarrubias 2020).
} 
a more (self)-sustainable pattern of growth has become current again, as well as controversial. Although the automotive industry in integrated peripheries is based on state-of-the-art factories and technologies, production, organization, and strategic functions are externally controlled through foreign ownership. Due to the rapid internationalization of the supplier industry, also the vast majority of suppliers in integrated peripheries are foreign subsidiaries that tend to assemble components or modules from imported parts or supplied by other foreign subsidiaries. Consequently, the existence of domestic suppliers and their capabilities are not important factors in the location decisions of foreign assembly firms.

The creation of clusters - which bring together a multiplicity of suppliers and auxiliary services around the main OEMs - the exceptional growth in production and exports, the direct and indirect creation of jobs, have been cited as indication of positive linkages ${ }^{13}$. However, in his analysis of the CEE integrated periphery, Pavlínek $(2020,530)$ concludes that "between 2005 and 2016, the benefits of large FDI in the automotive industry did not significantly spread from foreign to domestic firms in the form of spill-overs (Pavlínek and Zizalova, 2016; Pavlínek, 2018)". He estimated that in Eastern Europe only 5\% of jobs created were due to domestic firms and only about one-quarter of plants perform innovation tasks such as the introduction of new products and technologies (Krzywdzinski 2019). Overall, the recent literature on integrated peripheries in the CEE found little spill-over effects of foreign investments on domestic industry, highlighting the prevalence of a dependent type of development in the automotive industry.

Digital transformation raises a further question about the future development of the automotive industry in the CEE periphery. The period of rapid expansion of the CEE automotive industry related to the opening up of CEE to foreign trade and FDI in the 1990s and European Union membership in the 2000s has come to an end, coinciding with the 2008-2009 global economic crisis. Pavlínek et al. (2017, p. 6) observe that "although the FDI-driven development of the CEE automotive industry has continued in the aftermath of the economic crisis, it is no longer predominantly based on building new greenfield factories but increasingly on consolidating the existing spatial structure of the automotive industry in the form of expanding profitable investments through reinvestment." Also, investment in the components industry is likely to continue at significantly lower levels than in the period prior to the 2008-2009 economic crisis since automotive supplier networks are now already established in CEE (ibid. p. 10). The consolidation phase would require a much more selective functional upgrading of the CEE automotive industry, which is crucial for maintaining the competitiveness of the CEE automotive industry. Digital technologies may facilitate the further decentralization of advanced activities including engineering, design and software development across produc-

${ }^{13}$ Bai et al. (2020, fn 5), for instance, write that "There exists a large body of work documenting the positive impact of trade and FDI on the development of the local intermediate inputs market and spill-over via backward linkages". See the references quoted in the footnote. 
tion networks, allowing integrated peripheries to accumulate technological and R\&D activities that have been traditionally located in core, headquarters locations. Conversely, a pessimistic view posits that Industry 4.0 technologies may undermine the key comparative advantage of peripheral producers - lower labor costs and labor flexibility - and automate some of the knowledge-intensive activities performed by engineers in production locations (Drahokoupil 2020).

Electric vehicles and autonomous driving may represent even greater risks for the productive structure of the CEE countries, which is particularly focused on engines, transmissions and mechanical parts. The challenge is to leverage the traditional tools - low labor cost and public incentives - to attract new foreign investment for the production of batteries, and the retool of the existing plants for the production of electric and autonomous vehicles.

The issue is controversial in the case of Mexico. The insufficient development of the domestic value chain, both in terms of coverage of the various stages and in terms of technological and qualitative capabilities, is emphasized by several authors (Carrillo 2018; Equipo Roma 2019). It is argued that reliance on FDI for the development of the industry has insulated the foreign owned, technological advanced part from the rest of the value chain. In these conditions, exports were not such a strong contributor to economic growth as maintained: domestic production did not substitute for imports. Continued dependence on imported parts meant that national suppliers could not be integrated into the value chain (Castellanos, 2010). The dependence of the Mexican automotive industry on the strategic decisions of global players (on the re-organization of the various segments of their GVCs) is considered a factor of great vulnerability, especially in a context of rapid change in the patterns of consumption, technologies and international trade agreements.

In 2012, a case study of the supplier network in the automotive cluster led by Ford Motor Company in Hermosillo, Mexico (Contreras et al, 2012) found that a new trend of knowledge-intensive small local companies had emerged, providing higher value services and playing more important roles in the supply chain. Conversely, more recent studies (Carrillo 2018; Covarrubias 2020) based on exports data could not find positive effects, describing the Mexican automotive structure as a "pyramid without a base" (see fig. 5 in Carrillo 2018). It is to be noted, however, that exports are a bad indicator when analyzing the magnitude of spill-over effects, since Tier-2 and Tier-3 firms are more likely to produce for the local market, supplying directly Tier- 1 and Tier-2, which are the ones that ultimately export. An unequivocal answer can only come from production data (Table 3) and/or from direct surveys of the capabilities of the domestic structure.

In the next section, we analyze the joint effects of the digital transformation and the new Treaty on Mexico's domestic value chains. Our analysis is based on a series of interviews that we conducted in 2018 and 2019 with a number of Tier-1 and Tier-2 firms in Mexico. 
Table 3 The size distribution of firms in the Mexican automotive sub-sectors

\begin{tabular}{|c|c|c|c|c|c|c|c|c|}
\hline codigo_act & $\begin{array}{r}0 \text { a } 5 \\
\text { personas }\end{array}$ & $\begin{array}{r}6 \text { a } 10 \\
\text { personas }\end{array}$ & $\begin{array}{r}11 \text { a } 30 \\
\text { personas }\end{array}$ & $\begin{array}{r}31 \text { a } 50 \\
\text { personas }\end{array}$ & $\begin{array}{r}51 \text { a } 100 \\
\text { personas }\end{array}$ & $\begin{array}{r}101 \text { a } \\
250 \text { per.. }\end{array}$ & $\begin{array}{r}251 \mathrm{y} \\
\text { mãis pe.. }\end{array}$ & $\begin{array}{r}\text { Grand } \\
\text { Total }\end{array}$ \\
\hline 336120_Heavy Duty Truck Manufacturing & 7 & 4 & 13 & 4 & 3 & 2 & 12 & 45 \\
\hline 336310_MV_Gasoline Engine and Engine Parts Manufacturing & 35 & 6 & 15 & 15 & 14 & 17 & 54 & 156 \\
\hline 336320_MV_Electrical and Electronic Equipment Manufacturing & 71 & 14 & 25 & 29 & 45 & 41 & 241 & 466 \\
\hline 336330_MV_Steering and Suspension Components (except Spring) Manufactur.. & 12 & 9 & 9 & 11 & 8 & 14 & 31 & 94 \\
\hline 336360_MV_Seating and Interior Trim Manufacturing & 80 & 7 & 21 & 20 & 24 & 22 & 78 & 252 \\
\hline 336370_MV_Metal Stamping & 56 & 22 & 36 & 18 & 18 & 22 & 35 & 207 \\
\hline 336390_Other_MV_Parts Manufacturing & 110 & 34 & 50 & 30 & 43 & 44 & 156 & 467 \\
\hline Grand Total & 882 & 242 & 311 & 171 & 228 & 214 & 693 & 2.741 \\
\hline
\end{tabular}

Source: authors' elaboration on INEGI data base (INEGI Instituto Nacional de Estadística y Geografía (México), 2019), download 01/10/2019

\section{Impact of the new trade agreement and digital transformations on the Mexican sup- ply chain}

Free Trade vs. regional blocs

In recent years the automotive industry has been shaken by winds of trade war. From the repeal of NAFTA, to the imposition of tariffs on aluminum and steel, to the tariff war with China, and the threat of imposing tariffs on European exports of vehicles, there is no end in sight to the trade war launched by President Trump (and it is not certain that a change in the presidency will entail a radical change in US trade policy). ${ }^{14}$ On the European front, Brexit negotiations are fueling acrimony in inter-European relations and sowing uncertainty in firms' strategies.

Studies attempting to quantify the effects of restrictive trade policies find substantial trade and welfare losses due to the current close integration of production networks that amplify the adverse effects of protectionist policies, an argument made more compelling by the disruptions caused by Covid-19. Higher tariffs and trade wars may induce firms to shorten or otherwise reshape their global supply chains (Blanchard, 2019). Even seemingly small tariffs can substantially disrupt global value chains through the difference between nominal and effective tariff rates (which depend on the share of value added in the total value of the product) and the relative costs of relocation and transhipment (Menon, 2019).

The challenge to free trade involves threats and opportunities, differently distributed. Who bears the cost of such a trade war may vary according to the distribution of the valued added along the GVC. Tariffs on intermediate inputs may ultimately be borne by upstream producers in the country imposing the tariff, thus affecting the competitiveness of domestic firms

${ }^{14}$ For instance, Joe Biden has rolled out a 'Made in America' plan, pledging to penalize companies that move jobs overseas and reward business that employ people in the US, to woo voters in the industrial Midwest (reported in the FT, September 10, 2020). 
that have to import them. ${ }^{15}$ Similarly, some of the producer-side benefits from trade protection enjoyed by local import-competing firms may be passed along to foreign capital (Blanchard, 2019). However, if trade disputes are perceived as a symptom of an enduring geopolitical struggle for global economic dominance, they are likely to increase uncertainty. Strategic sourcing and foreign investment decisions of globally engaged firms require reasonably certain and long-term perspectives. ${ }^{16}$ By increasing uncertainty, trade disputes, even if temporarily settled, are associated with a greater volatility in equity markets (Baker et al., 2019) that may discourage investment. All things considered, and given the degree of integration between the US and the Mexican production plants - in 2019 Mexico accounted for more than $30 \%$ of total US imports of transport equipment - Trump's threats of repealing the NAFTA Treaty without negotiating a new one were scarcely credible, dubbed as the "mere expression of a professional extortionist" (Castellanos, 2017). Trump's threat is scarcely credible also due to the ability of companies to circumvent the treaty constraints through cross-border accounting practices.

Within the GVC model of production, costs and benefits of higher tariffs may extend well beyond the immediate 'intentional' targets, to include countries and companies around the world, including the very country that imposed the new protection at the outset. Given the complex calculation required by companies, which must respond to changes in the global economic landscape and the increasing uncertainty created by across the board trade disputes, there is good reason to believe that global firms may not respond the way the importing country wants or expects.

Although the conclusion of the new Treaty (USMCA) ${ }^{17}$ brought relief among the Mexican companies and policy makers and raised optimism about prospects for new investment inflows, specifically in the automotive sector, to increase the share of regional content, its effects are far from certain (see the following section). All the main OEMs and their global Tiers-1, with the exception of Chinese companies, have already established plants in Mexico,

${ }^{15}$ The United Steelworkers union, which represents nearly one million US worker-members in manufacturing, metals, forestry and beyond - industries that employ workers up and down the value chain across myriad traded products - has been an outspoken critic of renegotiating NAFTA in general, and of the US steel and aluminum tariffs against Canada in particular (Blanchard 2019, 60-61).

${ }^{16}$ Brexit provides the most recent example. Nissan has announced a delay in the production of its flagship vehicle - Quashqai - to be produced at the Sunderland plant, until after the post-Brexit definition of trading rules (Campbell 2020).

17 The USMCA agreement has a very detailed series of norms and time progression of requirements for the automotive industry. Among these are: rules of origin requirements, that mandate that $75 \%$ of an automobile's value must come from within the region (up from 62.55 under NAFTA), plus specific quotas for steel and aluminum, and certain components. Labor related measures include a minimum wage requirement: 40 to 45 percent of the automobiles manufactured in North America must be made in factories that pay a minimum of $\$ 16$ per hour on average. This measure will be phased in during the first five years after USMCA ratification. Finally, Annex 23-A requires Mexico to pass legislation that improves the collective bargaining capabilities of labor unions, to comply with the International Labour Organization's Convention 98 on freedom of association and collective bargaining. 
located in spatial agglomerations in the Bajío's states and in some Northern states (Klier and Rubenstein, 2017). The question is whether the new, stricter conditions of the new Treaty will succeed in attracting new firms, diverting production from other developed or emerging economies. With OEMs' plants in Mexico running below full capacity, and barring significant changes in the composition of the US demand of passenger vehicles, it is reasonable not to expect a large flow of new investment from assemblers, with the possible notable exception of Chinese firms (Ortiz-Velasquez et al, 2019). The question then is how the new Treaty will affect suppliers. The increase in regional content is expected to set in motion a readjustment in the global supply chains that could eventually benefit the local production of components in Mexico, though its total net effects will depend on a number of factors. The first question concerns the domestic availability of crucial components (such as specialty steel and aluminum, engines, etc.) at the moment not produced domestically. The second question concerns the distribution of the increased production of parts and components between foreign firms (relocating part of the production from their plants abroad to Mexico) and Mexican Tier- 2 and Tier- 3 firms. A third possibility is represented by Tiers- 1 reshoring production from their Tier-2 and Tier-3 suppliers unable to respond to (or certify conformity with) the requirements imposed by the Treaty.

\section{Products' traceability}

The general goal of the USMCA is to increase the regional content of components of the vehicles produced in the region. In order to certify compliance with the USMCA requirements, the traceability of the products across the production processes along the entire supply chain becomes crucial, ${ }^{18}$ making essential also communication flows within the supply chain. That traceability is a critical issue, not only for compliance with the Treaty, appears obvious if one considers that the biggest transformation in the automotive industry has been the vertical disintegration of production, with the decentralization of products in modules coordinated by Tiers-1. When entering the lean production model, firms must introduce many changes in the production lines (special vacuum cleaning of components and packaging, among others) and products must be fully certified in order for the assembler to use those

\footnotetext{
18 Traceability is the capacity to verify the history, location or status of an item by means of documented identification. The first step towards complete, end-to-end visibility across supply chains requires merging serialization - that is, assigning unique identifiers to products as diverse as consumer goods and complex medical devices - with smart manufacturing and traceability. As products are tracked, they acquire a 'pedigree', which provides a wealth of information to companies and consumers. Disruptive technologies, such as artificial intelligence, the Internet of Things, block chain and collaborative platforms, can take traceability systems to a higher level, offering detailed reports on any product's status and movements and creating direct links between the various stakeholders along the supply chain, from producers to end users. Traceability analyzes what goes well or wrong and assesses the efficiency of the entire supply chain process with data management and analytics, right up to the point of sale to the final consumer, and beyond. Using data-centric traceability systems, stakeholders can share collected data and cross-reference information with connected systems anywhere in the supply chain. Fraunhofer IOSB (2018). The adoption of these new technologies involves the delicate problem of ownership and control of data, with obvious implications for the distribution of power within the value chain.
} 
components in its production line. These changes call for a general increase in the demand for devices and processes to secure effective traceability.

An essential step is represented by the digital twin of production processes, ${ }^{19}$ which is expected to be the frontier of digital technologies. It is usually referred to as the digital version of the production process that is developed and enhanced for product and process planning. However, in the companies that we visited in 2018, we observed that digital twin was used the other way around, that is, to obtain a digital representation of the ongoing production process which the company could use for simulation and optimization of its internal organization of production. Firms had added sensors along the many stages of their production processes to control operations and to have a digital representation of the analogic steps of the transformations (pressing, assembling, ...); data could then be processed to optimize production flows, input consumption, labor utilization, maintenance planning, and so on.

Making traceability effective by the adoption of digital technologies could start a sweeping transformation across the entire supply chain. It may represent an efficient support to Tiers1 and Tiers- 2 in certifying their compliance with the Treaty's requirements, in achieving quality control of products and ensuring the flexibility in the just-in-time programing of the flow of products.

Fulfilment of the requirements of the USMCA - in terms of regional origin of components, level of wages, percentage of steel from the region, and so on - supports, or requires, the transformation of the technologies within the company. In this sense, product traceability is considered a driving channel to digital transformation (RIETI and Motohashi, 2017; World Economic Forum, 2019). The question is whether Tiers-2 and Tiers-3 will be able to plan the transformation of their organization to keep up with digital transformation. Companies unable to keep the pace of traceability risk losing their customers. The managers of a Tier-1 company we interviewed stated that they were ready to comply with the requirements (origin, labor, steel) in the short-medium term and, if needed, they would internalize the production processes that their Tier-2 and Tier-3 suppliers were unable to certify. However, once it has been reshored, production may not necessarily be outsourced again.

Digital technologies can also provide better quality control and a more fluid flow of information across the supply chain, improving the quality of the products, and enhancing process and product innovation, cost benefits that are passed on to their customers. In fact, most innovation is grounded within the factories, in the shop floor. Quality control of products, cost reductions and product improvements are obtained from suppliers producing components in a better way, changing the component design, the material inputs, the processes.

Finally, digital technologies could provide the flexibility required to optimize the production process without relying solely on labor flexibility, which has been, so far, the main source of

${ }^{19}$ See Fraunhofer IOSB (2018) for a collection of essays about the present and potential application of digital twin, from its first definition by NASA in 2010 to Industry 4.0. 
adjustment (more shifts, work on Saturday and the weekend). Labor flexibility is no longer enough, since the present organization of production requires flexibility and control over all inputs to meet prompt delivery requirements and reduce costs: cost reduction can come from better inventories management and better and timely information, adjustment and compliance with the daily or weekly changes that their customers might require to improve customer services. Flexibility is mandated by the just-in-time, lean production organization of the entire vertical chain, which must respond in real time to information provided by the dealers in the car markets. Within this scheme, the burden of adjustment is shifted down the value chain, from the OEMs to Tiers-1, and from these to their Tier-2 and Tier-3 suppliers.

The intensity and methods of application of digital technology differ not only between countries, sectors, and companies, but also within companies. Digital transformation is local. In our interviews we observed that smart factories presented different degrees of overall integration within the company and in the value chain. While foreign companies work with the latest technology, there is a great number of small domestic, lower-tier producers that have difficulty in grasping the opportunities opened by the technology and equip themselves with the required competences and organization, a problem common also in developed countries, as their governments are well aware. ${ }^{20}$

\section{Obstacles to the digital path}

To meet the challenges of the new trade agreement and digital transformation, changes are needed in several interrelated domains that go beyond traceability: labor up-skilling, energy and digital infrastructure, logistics and integrated modernization of transports.

The Mexican automotive industry is concentrated in a few clusters, built around OEM and Tier-1 foreign firms. In these enclaves (that include other advanced engineering sectors) a thick network of firms and institutions may provide the humus on which innovations thrive, with spill-over effects across sectors. But new technologies require new competences. This is where Mexican firms can face the most serious obstacles. In the automotive clusters, retaining skilled/trained workers was considered one of the most pressing problems. However, in our interviews, we met teams led by young people, with up-to-date competences acquired in universities, polytechnics and technical institutions, testifying to the great effort underway to prepare for the digital transformation. ${ }^{21}$ We also observed the great number of women working at the assembly lines and as quality control managers. Yet only medium to large companies had the resources to internally provide training and desired services for workfamily balance that a minimal public welfare cannot provide.

${ }^{20}$ In Germany, for instance, the national industrial plan of Industrie 4.0 (BMBF, 2013) has spurred a series of policy programs to support SMEs all over the country, with almost 50 innovation intermediaries (Digital Hubs and Competence Centers) specifically targeting the needs of SMEs in the digital transformation.

${ }^{21}$ A group of students in the Polytechnic University is producing its own electrical car. They are just assembling what has been invented and designed elsewhere, but also simply copying requires mastering the technology. 
The automotive production process uses the territory heavily. In the automotive clusters all over the Bajío' states and the Northern states of Cohauila and Chihuahua, (Mexico Industrial Maps 2018), auto parts suppliers are concentrated close to their customers, 200 kilometers away at most. In the Mexico-US-Canada corridors, transport costs are kept low by overloading trucks that cannot be used in the US any longer and by exploiting drivers with long driving days. Transport infrastructure is overwhelmed by overloaded trucks and long queues. The poor state of transportation makes for a long journey to work. ${ }^{22}$

The direction of the new technological developments is still very uncertain. Being designed to serve the US market, Mexico's productive structure and its development reflect the evolution of US demand and policies, i.e. not yet very responsive to the green transition. Discussions of transition to electric vehicles and new mobility has just started. Some manufacturers of light motor vehicles installed in Mexico have announced investments in production lines of e-vehicles. Meanwhile, the federal government has reduced the tariffs on imports of some e-vehicles to support their demand. ${ }^{23}$ The new development in mobility may represent a serious challenge for the supply chain, strongly tilted towards producing engines and transmissions. Thus, transition to a sustainable industry cannot be left entirely to the (foreign) market. The government must act now to assist the development of the complementary assets related to electric vehicles: from the efficient and environmentally friendly production and distribution of electricity to supporting demand for electric vehicles, to influencing mobility patterns. Environmental regulation and safety travel conditions could support the transition to new vehicles and foster internal production, reducing the dependence on exports (as is happening in Europe and in China), with spill-over effects on the supply chain of components and other sectors of the economy.

\section{The challenges ahead}

Increasing competition, digital disruptions, new technologies related to connectivity, autonomy, sharing and electrification (CASE) threaten the established structure of the automotive industry and the comparative advantage of the countries in the macro-regions. Competition in saturated markets has forced OEMs to transform production processes to contain costs and better meet customer demands, increasing product variety and shortening production cycles. At the same time, the race to electric vehicles (EV) and autonomous vehicles (AV) demands huge investments entailing big risks. Leading manufacturers and automotive companies are responding to the mounting risks by forming new kinds of strategic alliances.

Traditionally companies opted for M\&A when looking to enter new markets, gain economies of scale or access new capabilities. Aware that the automotive industry, especially in the mass

\footnotetext{
${ }^{22}$ In cross border commuting from Mexico City DF to any locality in the surrounding Mexico State, for instance, passengers have to change to a different company running the service in the other state. Transport regulation could make commuting easier, breaking local monopolies, enhancing competition and obtaining better services.

${ }^{23} \mathrm{https}$ ://www.opportimes.com/tariffs-on-imports-of-electric-cars-eliminated/
} 
market, would have to restructure - concentrate in a few large groups, share knowledge, processes, costs and risks, and take advantage of technological convergence - they engaged in mergers and acquisitions (M\&A) and horizontal alliances, while structuring vertical networks with suppliers. Either bringing together firms with complementary differences or pooling together firms with supplementary similarities, these new groups shaped the global automotive industry into distinct strategic blocks that became a basis for competition within the industry (Trezzini Matta 2016).

\section{Software giants: partners or competitors?}

In recent years, the speed of disruption, the need to make bets on multiple products, services, sectors and technologies, the sheer size of the investments involved, and the uncertainty of the outcomes, meant that strategic alliances - whereby two independent companies remain separate entities but share resources or collaborate on projects for their mutual benefit - have become an increasingly attractive and flexible alternative. Thus, we "have seen a shift in alliance archetypes away from familiar horizontal alliances towards cross-sector strategic alliances - mainly with technology companies, as a means of accessing new disruptive technologies" (Weber-Rymkovska et al. 2017, p. 4). At the same time, traditional M\&A activity has shifted towards acquiring innovative technology start-ups (Figure 5). ${ }^{24}$ This trend has further accelerated in the most recent years, and especially after Covid-19. The press reports news of consolidation and partnership deals taking place on an almost daily basis Volkswagen and Argo, Hyundai and Aptiv, Fiat Chrysler and Waymo (Google's self-driving unit) are but a few recent examples of the deals signed in autonomous driving - with similar deals in electric vehicles, batteries, hydrogen fuel cells, sharing and mobility.

Tier-1 suppliers are also deeply involved in forging alliances with companies that were not traditionally engaged in the automotive industry. In fact, in the present organization of global value chains, the definition of the technological solutions has been passed on to the component suppliers. They are the ones on the forefront of technology changes: they develop proprietary technologies in continuous dialogue with the manufacturers and take responsibility for incorporating new technologies in the production process (Gaddi and Garbellini 2019, p. 69).

\footnotetext{
${ }^{24}$ The number of cross-sector alliances (involving the top 15 auto companies) has grown dramatically in recent years, from just a small number between 1998-2007 to13 in the first 9 months of 2017 alone, taking the total to 52 over the past decade (Weber-Rymkovska et al. 2017).
} 
Figure 5 - Changing alliances landscape in automotive industry 1998-2017

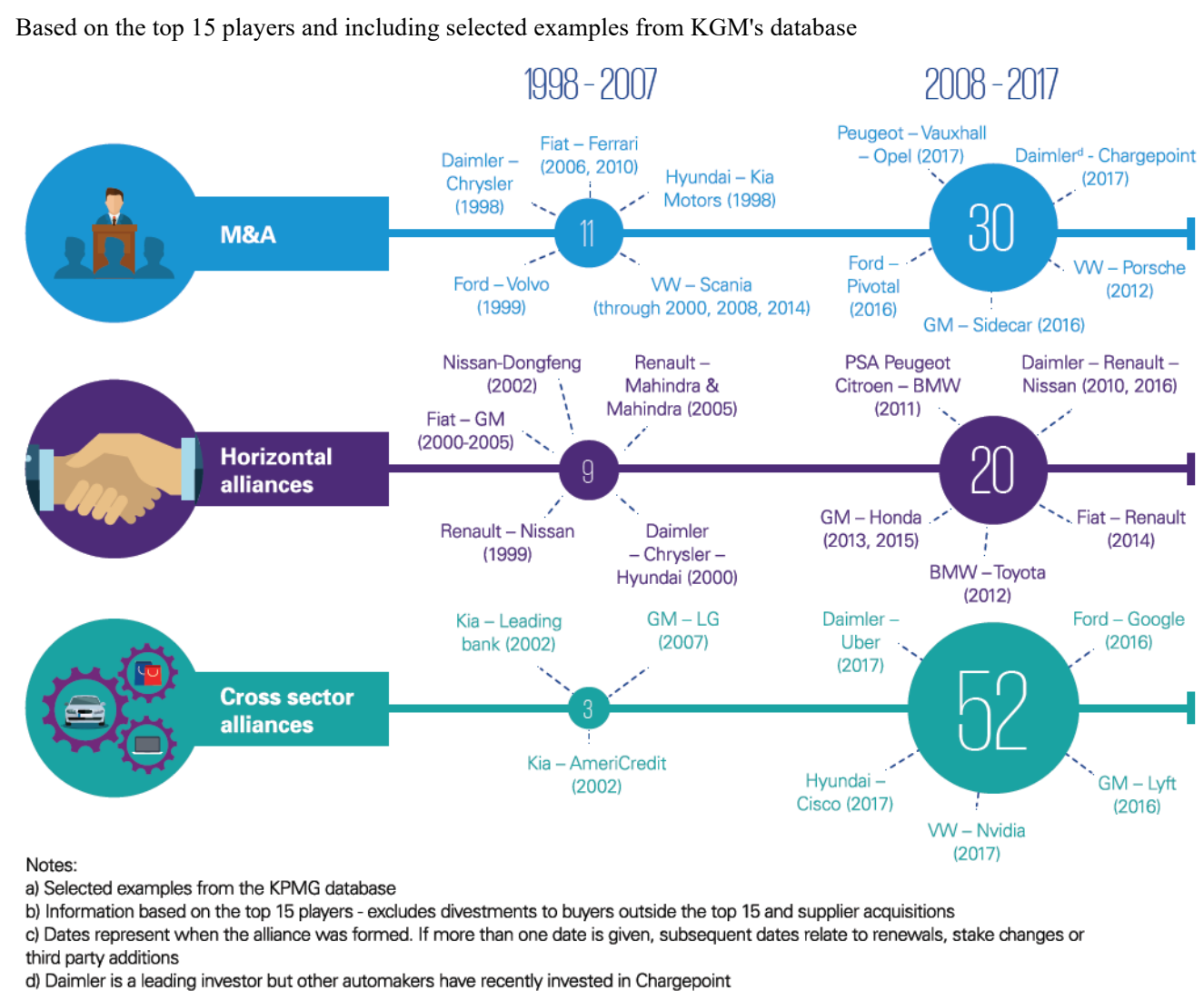

Source: Weber-Rymkovska et al. (2017).

\section{Computers on wheels}

As regions and players outside the traditional automotive set are gaining momentum, and a wave of technological trends is redefining mobility, the core competencies for future success are changing rapidly. The automotive product is changing: electronics and software play a major part and represent a significant share of the value of the vehicle. Changes in production processes require skills that have not, so far, been among the core competencies of automotive engineering and disrupt the fully integrated global supply chain model. The increasing relevance of (big) data and IT devices may shift the power from OEMs and suppliers to hightech and IT players.

Microsoft, for instance, has entered separate partnerships with five of the main car-makers (VW, Renault-Nissan-Mitsubishi, BMW, Daimler and Ford, that account for more than a third of global car production) to provide a fully connected vehicle platform that extends 
beyond over-the-air updates. According to Tara Prakriya, general manager of Azure mobility, the automotive arm of Microsoft's cloud division, "Microsoft's approach is to build trust with carmakers, supply them with technology and not compete with them" (McGee 2020). According to this narrative, Microsoft's role is to build the tools to help its partners find new revenues streams. ${ }^{25}$ This may not be the general strategy. According to Axel Schmidt, director of Accenture's global automotive practice, "They [Microsoft] are clearly focused on the back end and will never compete with the car producers... When you read the statements of [Amazon cloud unit] AWS and Google, it's a bit different [because] they are taking a disruptive, revolutionary approach, believing that there will be a significant market outside of the traditional carmakers" (McGee 2020).

These trends are likely to affect the distribution of profits between the various players, the quantity and quality of employment, and the fortunes of countries and regions. Public policies attempt to reduce dislocations and affect the level and localization of new investment through subsidies, tariffs or political pressures.

\section{New core-periphery clusters? China, Silicon Valley, Europe}

Electric mobility is developing at a rapid pace. In 2018, the global electric car fleet exceeded 5.1 million, up 2 million from the previous year and almost doubling the number of new electric car registrations (IEA 2019). With Covid-19 the trend accelerated beyond expectations.

The People's Republic of China is the world's largest electric car market. In spite of having one of the stricter policies aimed at reducing CO2 emissions, EU car makers have been slow in responding. In turn, in spite of the US bland policy towards green conversion, Tesla is currently the world's largest producer of BEVs (368,000 units in 2019), followed by the Chinese company BYD Auto (195,000 units in 2019). Until recently Tesla had one main production center in California, but it now also has a $\$ 5$ billion factory in Shanghai and is building a factory in Berlin (Morgan 2020).

All the major manufacturers have or are launching BEV models. There are also investment plans for battery manufacturing, where the EU delay is particularly severe, and which is currently dominated by East-Asian companies - LG Chem and Samsung in South Korea, CATL in China and Panasonic in Japan. In May 2018 the European Union "adopted the Strategic Action Plan for Batteries, that brings together a set of measures to support national, regional and industrial efforts to build a battery value chain in Europe, embracing raw material extraction, sourcing and processing, battery materials, cell production, battery systems, as well as reuse and recycling" (IEA 2019, p. 74). Public funding aimed at encouraging risk-taking

25 "The bigger opportunity for carmakers is generating recurring revenue streams from new services - most of which do not yet exist. It is here, says Sanjay Ravi, head of Microsoft's automotive strategy, where Microsoft's non-compete strategies should pay off" (McGee 2020). 
and investment in research and innovation in this field can be provided in derogation of the European state aid rules. Germany and France committed to fund battery production, to support the battery value chain and to enhance industrial co-operation for the production of battery cells.

With electronics and software playing a major part in the value of the vehicle, the automotive industry is attracting new investors from outside the industry - such as tech companies, venture capital and private equity players. These players dominate the investment in automotive and mobility start-ups. McKinsey (2019, p. 12) reports that since 2010, more than EUR 100 billion have been invested in mobility start-ups, of which 94 per- cent originated from players outside of the automotive industry. The mergers and acquisition (M\&A) volume in automotive tech start-ups reached EUR 39 billion in the US and EUR 26 billion in Asia-Pacific between 2014 and 2017. Investments from VC/PE players are mostly focused on the US and Asia, with Europe falling behind. The report forecasts that profits will shift even more towards new technologies and services, with more than 80 percent of the industry profit pool originating from CASE technologies and new business models. The question of employment is key in the transformation of the auto industry. Although the effects of automation on lowskilled labor may have been overstated (Pardi et al. 2020), electronics and software define a completely new product, requiring new components and new skills that have not, so far, been among the core competencies of automotive engineering. Thus, advances in electrification and automation may bring changes in the quality and the location of jobs gained and lost that go well beyond the automotive sector. "Based on the findings of the 2018 Fraunhofer IAO study "ELAB 2.0," alternative powertrains are less labor intensive than conventional combustion engines due to lesser complexity and a higher share of automation in production and assembly. With PHEV and BEV accounting for 40 percent of the powertrain mix in 2030, electrification could result - depending on the vertical integration of today's automotive OEMs and suppliers in e-mobility - in a net impact of 0.3 million fewer direct and indirect manufacturing jobs in Europe in 2030 compared to 2018" (quoted in McKinsey 2019, p. 32). The loss of jobs may be disastrous for integrated peripheries, though it will not spare core countries.

Cuts in wages and jobs started well before the Covid-19 outbreak and continued afterwards, with both OEMs and main suppliers in the US and Europe announcing jobs cuts, renegotiation of agreements with trade unions, closure or relocation of plants. The fall in demand in traditional markets and the need to invest massively in new markets, products, and technologies, has put OEMs under severe pressure to gain flexibility and cut costs. The burden of cutting costs has fallen on suppliers and labor. Parts producers have borne the brunt of the adjustment. This may suggest how one might interpret Daimler CEO's statement that: "we adjusted our production so quickly that in spite of Covid-19 we lowered our inventory and had a better working capital balance at the end of June than we had at the end of March" (Miller 2020b). 
Batteries vs fuel cells: Rival or complementary technologies?

Among clean/renewable energy technologies, fuel cells are increasing in importance for electric vehicles.

After having invested for years in battery electric vehicles (with electricity for charging batteries produced by nuclear plants), the Chinese Government, in April 2019shifted the incentives from that technology to the production of hydrogen. The Financial Subsidy Policy for the Promotion and Application of New Energy Vehicles now includes fuel cell technology and small unit production of hydrogen (see the policy release 138/2019) (Russo 2019, p. 244), a solution appropriate for countries that have dispersed locations of activities and residential areas.

The EU countries have massively subsidized the demand for electric vehicles and the production of batteries. Recently, the European Commission EC (2020) has singled out clean hydrogen as one of the essential areas to address in the context of the energy transition, identifying a number of possible avenues to support it. The EC estimates that Europe is highly competitive in clean hydrogen technologies manufacturing and is well positioned to benefit from a global development of clean hydrogen as an energy carrier. France and Germany have already earmarked 9 billion euros each for investment in fuel cell technology. This move meets with strong opposition to hydrogen within the car-making sector, on the argument that hydrogen technology is too complex and expensive. Indeed, faced with ever-stricter EU emissions regulation, car makers have already started huge investment in battery technology, and have accelerated the production of electric and hybrid vehicles both to avoid the large fines for non-compliance with EU emissions rules, and to take advantage of the huge stimulus packages announced by European governments to subsidize the purchase of EVs. Sunk costs plus the urgency to meet demand mean that they cannot afford to wait until the hydrogen technique becomes more affordable and less uncertain. Conversely, the EC's new drive for hydrogen is backed by Germany's mechanical engineering sector. It claims that the German industry already has "the necessary expertise for electrolysis and hydrogen storage... but needs solid commitments from the government to attract the necessary investment" (Miller 2020b). Hydrogen offers a unique opportunity to bridge the gap accumulated in battery technology vis-à-vis Asian countries across the entire value chain.

The games are still open. Technologies are still relatively new; the costs of production are high, as is uncertainty over future developments. Given the current state of technology, hydrogen is not yet competitive for passenger cars, but fuel cells can be used for trucks, buses, and industrial use: as production goes up, the cost of electrolysis goes down, making it competitive with electric cars.

\section{Open questions}

The automotive industry has been one of the most important growth engines for the developed countries of Europe and North America. After its first revolution, which unleashed a wave of delocalizations that resulted in a hierarchical regionalization of production and trade, 
it is now facing its second transformation. Competition is no longer between the traditional players, but extends beyond the automotive sector, to include batteries, software, connection, mobility. The rise of new competitors from emerging economies and would-be entrants from other sectors which compete in mastering the new digital and software technologies, threatens the established structure of the industry and the comparative advantage of countries.

The competencies of incumbents are no longer sufficient to master the digital innovation. Since R\&D in the new software and digital technologies are mostly developed in regions other than those dominated by OEMs, even the automotive industry's old core that based its supremacy in engineering excellence risks losing ground. If the car follows the destiny of the computer, where the value is increasingly in the software, a redistribution of profits across sectors is very likely.

As far as technologies in renewable energy and the development of EV are considered, they are still in their infancy. Trying to bridge the gap with South-Asian competitors, European OEMs have already committed large sums in the battery technology. Meanwhile, governments are encouraging investments in various technologies, including hydrogen. Competition between technologies make for an uncertain scenario, leaving room for the role of the state in coordinating and governing the change.

Public policy will also be needed because supply chains will be hit particularly hard, recently due to the extensive lockdown to cope with COVID-19 pandemic, impacting on suppliers with different intensities, and to the shift to electric batteries, which will result in a drastic reduction in the number of components. UBS has appraised that while the engine of a VW Golf contains 113 moving parts, the equivalent section of an electric Chevrolet Bolt has three: producers of parts for traditional engines risk being cast out (Campbell 2020). And as Thorsten Muschal, president of Clepa, which represents automotive suppliers in Europe, said: "the changes are far wider than simply the long-term phase-out of traditional engine makers" (ibid.). Semi-peripheries and integrated peripheries, that specialize in the supply of "traditional" product, may suffer more.

The current automotive transition is likely to open the way to a new restructuring of the comparative advantage of nations, with important consequences on the quantity and quality of employment. 


\section{References}

Bai, J., Barwick, P. J., Cao, S., \& Li, S. (2020). Quid Pro Quo, Knowledge Spillover, and Industrial Quality Upgrading: Evidence from the Chinese Auto Industry (No. w27644). National Bureau of Economic Research.

Baker, S., Bloom, N. and Davis, S. (2019). The extraordinary rise in trade policy uncertainty. VOX CEPR Policy Portal (blog) https://voxeu.org/content/five-surprising-things-about-new-usmcatrade-agreement.

Blanchard, E. (2019). Trade wars in the global value chain era. VOX CEPR Policy Portal (blog). https://voxeu.org/article/trade-wars-global-value-chain-era.

Brincks, C., Domański, B., Klier, T., \& Rubenstein, J. (2018). Integrated peripheral markets in the auto industries of Europe and North America. International Journal of Automotive Technology and Management, 18(1), 1-28. https ://doi.org/10.1504/IJATM.2018.090170

Campbell, P. (2020). Nissan delays production date of flagship vehicle in UK, The Financial Times, September, 8.

Campbell, P. (2020b). EV supply chains seek clearer visibility with blockchain, The Financial Times, September 9.

Carreto Sanginés, J., Pavone, P., Russo, M., Simonazzi, A. (2019). Digital upgrade in the automotive supply chain in Mexico, DEMB WP Series, 153.

Carreto Sanginés, J. (2020). The NAFTA: an obituary, Unam, mimeo

Carrillo, J. (2018). Manufactura dinamica en México y possibilidades de desarrollo regional:sectores automotriz y aeroespacial. In Enrique Dussel-Peters (ed.) Cadenas Globales de Valor, Mexico: UNAM. Facultad de Economía, 89-110.

Castellanos, J. (2017). The Automotive Industry Located in Mexico during the Presidency of Donald Trump. Gerpisa colloquium, Paris http://gerpisa.org/node/3764.

Castellanos, J., Alvarez, L., and Martin J.M. (2010). Performance and perspectives of the automotive industry in Mexico after the 2009 economic crisis, Gerpisa Colloquium.

Celi, G., Ginzburg, A., Guarascio, D., and Simonazzi, A. (2017). Crisis in the European Monetary Union: A core-periphery perspective. Routledge.

Coe, N. M., and Yeung, H. W. C. (2015). Global production networks: Theorizing economic development in an interconnected world. Oxford University Press.

Contreras, O. F., Carrillo, J., \& Alonso, J. (2012). Local entrepreneurship within global value chains: a case study in the Mexican automotive industry. World development, 40(5), 1013-1023. https://doi.org/10.1016/j.worlddev.2011.11.012Get rights and content

Covarrubias, A. (2020). The Boom of the Mexican Automotive Industry: From NAFTA to USMCA, In Covarrubias, A. and Perez, S.M.R. (eds.) New Frontiers of the Automobile Industry, Pal-grave, McMillan, 323-48.

Covarrubias, A. and Perez, S.M.R. (2020). Wrapping Up: The New Geographies and Frontiers of the AI have Arrived. Who is Taking the Lead? In Covarrubias, A. and Perez, S.M.R. (eds.) New Frontiers of the Automobile Industry, Palgrave, McMillan, 455-494.

Daft, R. L., and Weick, K. E. (1984). Toward a model of organizations as interpretation systems. Academy of management review, 9(2), 284-295.

Danyluk, M. (2018). Capital's logistical fix: accumulation, globalization, and the survival of capitalism. Environment and Planning D: Society and Space, 36, 630-647. 
Drahokoupil, J. (2020). Introduction: Digitalisation and automotive production networks in Europe. In Drahokoupil, J (ed.) The challenge of digital transformation in the automotive indus-try. Jobs, upgrading and the prospects for development, ETUI aisbl, Brussels, 7-22.

EC (2020). A hydrogen strategy for a climate-neutral Europe. Brussels, 8.7.2020

$\operatorname{COM}(2020) 301$ final

ERM (2017). European restructuring monitor, http://www.eurofound.europa.eu/.

Fraunhofer IOSB (2018). Industrial IoT - Digital Twin. visIT, Karlsruhe 2018. https:/www.iosb.fraunhofer.de/servlet/is/81047/visIT_1-2018.pdf?command=downloadContent\&filename=visIT_1-2018.pdf.

Gaddi, M. (2020). Technological and organisational innovation under Industry 4.0 - Impact on working conditions in the Italian automotive supply sector. In Drahokoupil, J (ed.) The challenge of digital transformation in the automotive industry. Jobs, upgrading and the prospects for development, ETUI aisbl, Brussels, 127-152.

Gaddi, M. and Garbellini, N. (2019). Automotive and Electric Mobility. UE/NGL European Parliamentary Group. Brussels, 2019.

Galgóczi, B. (2017). Why central and eastern Europe needs a pay rise. ETUI Research Paper-Working paper.

Gorgoni, S., Amighini, A., and Smith, M. (2018). Automotive international trade networks: A comparative analysis over the last two decades, Network Science 6 (4), 571-606.

Harvey, D. (2014). Seventeen Contradictions and the End of Capitalism. London: Profile Books.

Hoeft, F. (2020). Assessing organisational capabilities of incumbent car manufacturers in light of current influencing factors. Gerpisa Colloquium, Paris http://gerpisa.org/en/node/6055

IEA (2019). Global EV outlook 2019. https://webstore.iea.org/download/direct/2807?filename=global_ev_outlook_2019.pdf

INEGI, Instituto Nacional de Estadística y Geografía (México), various years. https://www.inegi.org.mx/

Klier, T. H., \& Rubenstein, J. M. (2017). Mexico's growing role in the auto industry under NAFTA: Who makes what and what goes where. Economic Perspectives, 6, 1-29.

Klier, T., \& Rubenstein, J. (2010). The changing geography of North American motor vehicle production. Cambridge Journal of Regions, Economy and Society, 3(3), 335-347. https ://doi.org/10.1093/cjres/ rsq024

Klier, T., \& Rubenstein, J. (2020). ICE Age Geography: Powertrain Sourcing in Europe and North America, Gerpisa

Krzywdzinski, M. (2014). How the EU's eastern enlargement changed the German productive model. The case of the automotive industry. Revue de la régulation. Capitalisme, institutions, pouvoirs, (15).

Krzywdzinski, M. (2019). Globalisation, decarbonisation and technological change: challenges for the German and CEE automotive supplier industry. In Béla Galgóczi (Hg.), Towards a Just Transition. Coal, Cars and the World of Work, Brussels: European Trade Union Institute, 215-241.

Lampón, J., Lago-Penas, S., \& Cabanelas, P. (2016). Can the periphery achieve core? The case of the automobile components industry in Spain. Papers in Regional Science, 95(3), 595-612. https://doi.org/10.1111/pirs.12146

Mc Gee, P. (2020). Microsoft sets sight on auto 'connectivity', The Financial Times, September 9. 
McKinsey (2019). Race 2050 - A Vision for the European Automotive Industry, January. https://www.mckinsey.com/ /media/mckinsey/industries/automotive\%20and\%20assembly/our\%20insights/a\%20long\%20term\%20vision\%20for\%20the\%20european\%20automotive $\% 20$ industry/race-2050-a-vision-for-the-european-automotive-industry.ashx

Menon, J. (2019). The knock-on consequences of the US-China trade tariffs on global value chains. VOX CEPR Policy Portal https://voxeu.org/article/knock-consequences-us-china-trade-tariffsglobal-value-chains.

Mexico Industrial Maps (2018). The Primer Industrial Site Establishment Tool. Mexico Industrial Maps https://mexicoindustrialmaps.com/parks/en/mexico.

Miller, J. (2020a). Daimler rules out expansion at home, The Financial Times, September 7.

Miller, J. (2020b). Daimler looks to the future with renewed zest, The Financial Times, 8 September.

Mordue, G. (2017). Doors closed and opportunities missed: Lessons from failed automotive investment attraction in Canada in the 1980s. Canadian Public Policy, 43(S1), S43-S56. https://doi.org/10.3138/cpp.2016-022

Mordue, G., \& Karmally, D. (2020). Frontier Technologies in Non-Core Automotive Regions: Autonomous Vehicle R\&D in Canada. Canadian Public Policy, 46(1), 73-93. https://doi.org/10.3138/cpp.2019-015

Mordue, G., \& Sweeney, B. (2017). The commoditisation of automotive assembly: Canada as a cautionary tale. International Journal of Automotive Technology and Management, 17(2), 169-189. https://doi.org/10.1504/IJATM.2017.084804

Mordue G, Sweeney B. (2020). Neither core nor periphery: The search for competitive advantage in the automotive semi-periphery. Growth and Change 51:34-57. https ://doi.org/10.1111/grow.12354

Morgan, J. (2020). Electric vehicles: the future we made and the problem of unmaking it. Cambridge Journal of Economics, 44(4), 953-977.

Negocios ProMéxico (2015). The Mexican automotive industry A success story with a promising future. Special Feature. https://docplayer.net/3922540-The-mexican-automotive-industry-leading-the-world.html

OICA (2018). World Motor Vehicle Production by Country and Type, 1997-2017. Paris: Organisation Internationale des Constructeurs d'Automobile.

Ortiz-Velásquez, S., Marcial-Flores, A., \& Arteaga-García, A. (2019). China in the automotive industry in Mexico: perspectives and challenges in the transition from NAFTA to T-MEC, Gerpisa Colloquium.

Pardi, T., Krzywdzinski, M., Luethje, B. 2020. Digital manufacturing revolutions as political projects and hypes:: evidences from the auto sector, ILO Working Paper 3 (Geneva, ILO).

Pavlínek, P. (2018). Global production networks, foreign direct investment, and supplier linkages in the integrated peripheries of the automotive industry. Economic Geography, 94(2), 141-165. https://doi.org/10.1080/00130095.2017.1393313

Pavlínek, P. (2020). Restructuring and internationalization of the European automotive industry. Journal of Economic Geography, 20(2), 509-541.

Pavlínek, P., \& Zizalova, P. (2016). Linkages and spillovers in global production networks: Firmlevel analysis of the Czech automotive industry. Journal of Economic Geography, 16(2), 331363. https://doi.org/10.1093/jeg/lbu041 
Pavlínek, P., Aláez-Aller, R., Gil-Canaleta, C., \& Ullibarri-Arce, M. (2017). Foreign Direct Investment and the development of the automotive industry in Eastern and Southern Europe. ETUI Research Paper-Working Paper.

RIETI and Kazuyuki Motohashi (2019). Survey of Big Data Use and Innovation in Manufacturing Firms, December. https://rive.google.com/file/d/1rsam4WUeJqqUwpwkzZ7YgFT4AD0orOvP/view.

Russo, M. (2019). Digital transformation in the automotive supply chain: China, Germany, Italy and Japan in a comparative perspective, DEMB Working Paper Series, Università di Modena e Reggio Emilia, n. 151. http://merlino.unimo.it/campusone/web_dep/wpdemb/0151.pdf.

Russo, M., Alboni, F., Carreto, J., Righi, S., Simonazzi, A. (2020). Mapping specialisations in the automotive international trade: a multilayer network analysis, INET Interim Report, mimeo.

Singer, H. W. (1950). The distribution of gains between borrowing and investing countries. American Economic Review, 40(2), 473-485.

Sturgeon, T., Van Biesebroeck, J., \& Gereffi, G. (2008). Value chains, networks and clusters: Reframing the global automotive industry. Journal of Economic Geography, 8(3), 297-321. https ://doi.org/10.1093/jeg/lbn007

Teece, D. J. (2018). Tesla and the reshaping of the auto industry. Management and Organization Review, 14(3), 501-512.

Teece, D. J. (2019). China and the reshaping of the auto industry: A dynamic capabilities perspective. Management and Organization Review, 15(1), 177-199.

Teece, D., Peteraf, M., \& Leih, S. 2016. Dynamic capabilities and organizational agility: Risk, uncertainty, and strategy in the innovation economy. California Management Review, 58(4): 13-35

Trezzini Matta, F. (2016). Global Networks and Competitive Strategic Alliances in the Automotive Industry. The Case of declining Europe. PhD thesis, Bicocca 2015-2016 https://boa.unimib.it/retrieve/handle/10281/148092/210616/phd_unimib_700973.pdf

Weber-Rymkovska, J., Rassloff, J., Bhaiji, M. and Zinke, C. (2017). Strategic alliances: a real alternative to M\&A? KPMG International https:/assets.kpmg/content/dam/kpmg/xx/pdf/2017/11/strategic-alliances-toolkit.pdf

World Economic Forum (2019). 5 ways traceability technologies can lead to a safer, more sustainable world. World Economic Forum, September 13. https://www.weforum.org/agenda/2019/09/5ways-traceability-technology-can-lead-to-a-safer-more-sustainable-world/.

Zhu, T. (2007). Rethinking import-substituting industrialization: Development strategies and institutions in Taiwan and China. Institutional Change, United Nations University Press: Tokio, 261279. 
Table A1 - Percentage of trade flows by commodity and by group, in the years 1993, 2003, 2013, 2017.

Groups are listed in decreasing order of their share of export in 1993. Commodities are listed according to their SITC code

\begin{tabular}{|c|c|c|c|c|c|c|}
\hline $\begin{array}{l}\text { Group } \\
\text { Description }\end{array}$ & $\begin{array}{l}\text { Sitc } \\
\text { Rev.3 }\end{array}$ & Commodity description & 1993 & 2003 & 2013 & 2017 \\
\hline Miscellaneous & Total & & $64.74 \%$ & $66.13 \%$ & $64.58 \%$ & $65.69 \%$ \\
\hline \multirow[t]{11}{*}{ Parts } & 7841 & Chassis fitted with engines, for the motor vehicles of groups 722,781 & $1.20 \%$ & $0.61 \%$ & $0.51 \%$ & $0.38 \%$ \\
\hline & 78421 & Bodies (including cabs), for the motor vehicles of group 781 & $0.38 \%$ & $0.43 \%$ & $0.77 \%$ & $0.44 \%$ \\
\hline & 78425 & Bodies (including cabs), for the motor vehicles of groups 722,782 & $0.82 \%$ & $1.10 \%$ & $0.80 \%$ & $0.82 \%$ \\
\hline & 78431 & Bumpers and parts thereof, of the motor vehicles of groups $722,781,782$ & $1.30 \%$ & $1.07 \%$ & $1.03 \%$ & $1.07 \%$ \\
\hline & 78432 & Other parts and accessories of bodies (including cabs) & $12.44 \%$ & $13.96 \%$ & $11.13 \%$ & $11.55 \%$ \\
\hline & 78433 & Brakes and servo brakes and parts thereof, of the motor vehicles of group & $5.04 \%$ & $5.61 \%$ & $5.06 \%$ & $5.15 \%$ \\
\hline & 78434 & Gearboxes of the motor vehicles of groups $722,781,782$ and 783 & $7.61 \%$ & $7.65 \%$ & $10.22 \%$ & $10.24 \%$ \\
\hline & 78435 & Drive-axles with differential, whether or not provided with other transmission & $1.47 \%$ & $1.19 \%$ & $3.88 \%$ & $3.82 \%$ \\
\hline & 78436 & Non-driving axles and parts thereof, of the motor vehicles of groups 722 & $1.11 \%$ & $1.20 \%$ & & \\
\hline & 78439 & Other parts and accessories of the motor vehicles of groups $722,781,782$ & $32.85 \%$ & $32.79 \%$ & $30.78 \%$ & $31.72 \%$ \\
\hline & 82112 & Seats of a kind used for motor vehicles & $0.51 \%$ & $0.52 \%$ & $0.40 \%$ & $0.49 \%$ \\
\hline \multirow{7}{*}{$\begin{array}{l}\text { Engines and } \\
\text { Parts }\end{array}$} & Total & & $19.45 \%$ & $18.98 \%$ & $18.56 \%$ & $18.40 \%$ \\
\hline & 71321 & Reciprocating internal combustion piston engines for propelling vehicles & $0.51 \%$ & $0.41 \%$ & $0.36 \%$ & $0.46 \%$ \\
\hline & 71322 & Reciprocating internal combustion piston engines for propelling vehicles & $9.91 \%$ & $8.30 \%$ & $5.83 \%$ & $5.86 \%$ \\
\hline & 71323 & Compression ignition internal combustion piston engines (diesel or semi-diesel) & $3.61 \%$ & $5.27 \%$ & $6.09 \%$ & $5.32 \%$ \\
\hline & 77831 & Electrical ignition or starting equipment of a kind used for spark ignition & $2.86 \%$ & $2.47 \%$ & $2.68 \%$ & $2.63 \%$ \\
\hline & 77833 & Parts of the equipment of heading 778.31 & $0.70 \%$ & $0.64 \%$ & $0.57 \%$ & $0.49 \%$ \\
\hline & 77834 & Electrical lighting or signalling equipment & $1.87 \%$ & $1.89 \%$ & $3.02 \%$ & $3.64 \%$ \\
\hline Rubber and & Total & & $8.74 \%$ & $7.53 \%$ & $9.73 \%$ & $8.17 \%$ \\
\hline \multirow[t]{9}{*}{ Metal Parts } & 6251 & Tyres, pneumatic, new, of a kind used on motor cars (including station wagon) & $5.97 \%$ & $5.17 \%$ & $6.81 \%$ & $5.76 \%$ \\
\hline & 62551 & Tyres, pneumatic, new, other, having a herring-bone or similar tread & $0.57 \%$ & $0.41 \%$ & $0.62 \%$ & $0.44 \%$ \\
\hline & 62559 & Tyres, pneumatic, new, other & $0.56 \%$ & $0.50 \%$ & $0.90 \%$ & $0.61 \%$ \\
\hline & 62591 & Inner tubes & $0.31 \%$ & $0.13 \%$ & $0.15 \%$ & $0.10 \%$ \\
\hline & 62592 & Retreaded tyres & $0.17 \%$ & $0.09 \%$ & $0.11 \%$ & $0.10 \%$ \\
\hline & 62593 & Used pneumatic tyres & $0.18 \%$ & $0.08 \%$ & $0.08 \%$ & $0.05 \%$ \\
\hline & 62594 & Solid or cushion tyres, interchangeable tyre treads and tyre flaps & $0.15 \%$ & $0.12 \%$ & $0.18 \%$ & $0.14 \%$ \\
\hline & 69915 & Other mountings, fittings and similar articles suitable for motor vehicle & $0.80 \%$ & $1.00 \%$ & $0.86 \%$ & $0.93 \%$ \\
\hline & 69961 & Anchors, grapnels and parts thereof, of iron or steel & $0.04 \%$ & $0.03 \%$ & $0.03 \%$ & $0.03 \%$ \\
\hline Electrical and & Total & & $7.07 \%$ & $7.36 \%$ & $7.13 \%$ & $7.74 \%$ \\
\hline \multirow[t]{4}{*}{ Electric Parts } & 76211 & Radio broadcast receivers not capable of operating without an external source & $3.36 \%$ & $2.78 \%$ & $1.71 \%$ & $1.29 \%$ \\
\hline & 76212 & Radio broadcast receivers not capable of operating without an external source & $0.38 \%$ & $0.23 \%$ & $0.16 \%$ & $0.18 \%$ \\
\hline & 77812 & Electric accumulators (storage batteries) & $3.11 \%$ & $4.22 \%$ & $5.12 \%$ & $6.19 \%$ \\
\hline & 77823 & Sealed-beam lamp units & $0.21 \%$ & $0.13 \%$ & $0.14 \%$ & $0.09 \%$ \\
\hline
\end{tabular}

